\title{
'Peritoneal Mice' A Peritoneal Loose Body in Pelvic Cavity of 70 Years Old Man, An Incidental Finding - A Case Report
}

\author{
Shashikala Kosam ${ }^{1}$, Pratima Kujur ${ }^{2}$, Veenapani Mire ${ }^{3}$ \\ ${ }^{1}$ Assistant Professor Department of Pathology, Pt J.N.M Medical College, Raipur Chhattisgarh (C.G.) India 492001 \\ ${ }^{2}$ Professor and Head of Department, Department of Pathology, Pt J.N.M Medical College, Raipur (C.G.) India 492001 \\ ${ }^{3}$ 2nd year Post graduate Student Department of Pathology, Pt J.N.M Medical College, Raipur Chhattisgarh (C.G.) India 492001
}

\begin{abstract}
Peritoneal loose bodies, or peritoneal mice, are rare asymptomatic lesions that are usually found as an incidental finding during abdominal surgery or autopsy. Giant peritoneal loose bodies are rare. Giant loose bodies, measuring more than 5 cm, are rare and only a few cases are reported in the literature. These bodies are usually infarcted appendices epiploicae, which become detached and appear as a peritoneal loose body in the abdominal cavity. We present a rare case large peritoneal loose body "peritoneal mice" found during a laparoscopic abdominal surgery in a 70 years old male patient. Usually these peritoneal loose bodies are left untreated until complication arises.
\end{abstract}

Keywords: Appendices epiploicae , boiled egg, fat necrosis, Peritoneal loose body

\section{Introduction}

Peritoneal loose bodies are rare in occurence. They are found incidentally at laparotomy or autopsy by accident and often they have no clinical relevance, whereas sometimes they become symptomatic. Exact etiopathogenesis is not known but the most common origin of these bodies are infracted appendices epiploicae that get detached and lie loose in the peritoneum and get saponified and later calcification occur [1, 2]. These loose bodies are usually incidental findings that do not require any specific treatment until they become complicated [3-6].

They are usually small sized, like peas $(1-2 \mathrm{cms})$. The loose body measuring more than $5 \mathrm{~cm}$ are even rarer and termed as Giant loose body [3, 7]. Here we are reporting a case of peritoneal loose body in $70 \mathrm{yrs}$ old patient.

\section{Case Report}

A 70 years old male was admitted in casualty ward with complaints of acute abdominal pain, vomiting, and not passing flatus or feces since 2-3 days. Patient had history of past abdominal discomfort. On general physical examination patient was afebrile, moderately built, moderately nourished. Laboratory investigations showed normal haemoglobin value, raised total leukocyte count, raised blood urea and creatinine and urine examination were within normal limit. USG abdomen showed mass in pelvic cavity. On laparoscopic exploration a well defined egg like structure was identified in pelvic cavity. This egg like structure and part of omentum preserved in $10 \%$ formalin solution was sent in two containers for histopathological evaluation.

\section{Histopathological examination}

On gross histopathologic examination, the peritoneal loose body was oval in shape with boiled egg appearance, measuring $5 \mathrm{~cm}$ diameter, well circumscribed, unencapsulated. External surface was smooth shiny, white in colour. On cut section single calcified core identified which was hard in consistency, peripheral part was firm.(Figure a and Figure b). Microscopic examination of egg like structure revealed dystrophic patchy calcification, with psammomatous body formation and concentric laminar pattern seen and part of omentum showed fat necrosis. (Figure $\mathrm{c}$ and Figure d)

\section{Discussion}

Peritoneal loose bodies are very rare. They are also called peritoneal mice. There is limited information about the incidence of peritoneal loose body. Peritoneal loose body is more common in males. The incidence rate ratio between male and female is 18:4. The age span of patients at the time of diagnosis ranges from 2 months to 79 yrs and the majority occurs between $50-70$ yrs old. Most loose body ranges from 5 to $25 \mathrm{~mm}$ in size and generally do not cause any symptom. When the maximum diameter reaches more than $50 \mathrm{~mm}$, they can be called giant peritoneal loose bodies. The largest peritoneal loose body measured $95 \times 86 \mathrm{~mm}$ and was reported by Mohri et al. [8] in 2007.

In our case the peritoneal loose body size was $5 \mathrm{~cm}$ diameter and cause acute abdominal discomfort. This type of study was also observed by various authors [Table no.1]

Littre in the year 1703 was the first to report a case of peritoneal loose body. Though the exact pathogenesis is unknown, it was Virchow (9) who proposed the sequential changes of the peritoneal mice, in his study in the year 1863.

Epiploic appendages referred as appendices epiploicae are 1$2 \mathrm{~cm}$ thick and 0.5 to $5 \mathrm{~cm}$ long, supplied by one or two small colonic end arteries and small draining vessels [10].Patterson in 1933 suspected that ischemia as a result of torsion or inflammation is dominant etiological factor that led to infarction or amputation.

\section{Volume 6 Issue 1, January 2017




\section{International Journal of Science and Research (IJSR) \\ ISSN (Online): 2319-7064}

Index Copernicus Value (2015): 78.96 | Impact Factor (2015): 6.391

Harrigan first described free-lying appendix epiploicae [11]. The term loose body implies something which has worked free from the lining of abdomen, resembling the loose bodies found in joints [12]. Exact etiology is not known. Possible sources include: (1) appendix epiploicae, (2) omentum [13], (3) autoamputated adnexa, or (4) fat tissue in the pancreas [5]. The most common source is appendix epiploicae. It is believed that the process is sequential. First, chronic torsion of the appendix epiploicae occurs, and the blood supply is shut off, followed by saponification and calcification of fat tissue. Finally, the appendix epiploicae detaches from the colon due to atrophy of the pedicle and becomes a peritoneal loose body.

Many authors suggest that once an appendix epiploicae gets saponified and calcified the exudative serum fluid (rich in protein) accumulates around it and, because of increased temperature in the peritoneal cavity; it gives the appearance of a boiled egg. With time, the size of the peritoneal body increases because of a gradual deposition of body serum at the periphery. Sometimes the free peritoneal body attaches to the omentum and receives a blood supply from it [14].

In our case histological finding suggest that peripheral white part is formed by deposition of peritoneal serum and central yellowish part is formed by saponified and calcified appendices and giving the appearance of boiled egg. The differential diagnosis associated with peritoneal loose body include the following: (1) benign disease: leiomyoma, rhabdomyomas, teratoma, and fibroma; (2) malignant disease: colorectal cancer, ovarian cancer, and metastases; (3) calculous disease: urinary stones, gallstones, and appendix stones; (4) tubercular granuloma; and (5) others: calcification of lymph nodes, lymphoma, and foreign bodies. $\mathrm{CT}$ and MRI can be performed to distinguish peritoneal loose bodies from other lesions [15].

\section{Conclusion}

Peritoneal loose bodies are rare and in most of the cases smaller in size. Even though giant loose bodies are very rare and a few cases were reported in the literature. They should be considered in the differential diagnosis of a mobile lesion in the pelvis and abdomen. Histopathological confirmation is mandatory so as to rule out calcified intraperitoneal masses. A diagnostic laparoscopy can be done for removal of symptomatic peritoneal mice to obviate unnecessary surgery and to minimize morbidity.

\section{References}

[1] Desai HP, Tripodi J, Gold BM, Burakoff R: Infarction of an epiploic appendage. Review of the literature. $\mathrm{J}$ Clin Gastroenterol 1993, 16(4):323-325.

[2] Farmlett EJ, Fishman EK, Jones B, Siegelman SS: Torsion of lipoma of appendix epiploicae: CT evaluation. J Comput Assist Tomogr 1985, 9(2):366368.

[3] Ghosh P, Strong C, Naugler W, Haghighi P, Carthers JM: Peritoneal mice implicated in intestinal obstruction: report of a case and review of the literature. J Clin Gastroenterol 2006, 40(5):427-430.
[4] Bhandarwar AH, Desai VV, Gajbhive RN, Deshraj BP Acute retention of urine due to a loose peritoneal body. Br J Uro 1996, 78(6):951-952.

[5] Takabe K, Greenberg Ji, Blair SL: Giant peritoneal loose bodies. J Gastrointest Surg 2006, 10(3):465-468.

[6] Takada A, Moriya Y, Muramatsu Y, Sagae T: A case of giant peritoneal loose bodies mimicking calcified leiomyoma originating from the rectum. Jpn J Clin Oncol 1998, 28(7):441-442.

[7] Shepherd JA peritoneal loose body causing retention of urine br j surg 1951, 39, 185-7

[8] Mohri T, Kato T, Suzuki H. A giant peritoneal loose body: report of a case. Am Surg. 2007;73(9):895-6.

[9] Borg SA, Whitehouse GH, Griffiths GJ. A mobile calcified amputed appendix epiploica. Am J Rentogenol. (1976; 127: 349-50).

[10] Ross JA: Vascular loops in appendices epiploicae: their anatomy and surgical significance with a surgical pathology of appendices epipolicae. Br.J Surgery (1950\{148\}: 464-4)

[11] Harrigan AH. Torsion and inflammation of the appendix epiploicae. Ann Surg. 1917;66:467-78.

[12] Ross JA, McQueen A. Peritoneal loose bodies. British J Surg. 1947/48;35:313-7.

[13] Ghabremani GG, White ME, Hoff FL, Gore RM, Miller JW, Christ ML.Appendices epiploicae of the colon: radiologic and pathologic feature. Radiographics. 1992;12:59-77.

[14] Sewkani A, Jain A, Maudar K, Varshney S. 'Boiled egg' in the peritoneal cavity-a giant peritoneal loose body in a 64-year-old man: a case report. J Med Case Rep. 2011;5:297.

[15]Zhang et al. World Journal of Surgical Oncology (2015) 13:118

[16] Hedawoo JB, Wagh A. Giant peritoneal loose body in a patient with haemorrhoids. Trop Gastroenterol. 2010;31(2):132-3.

[17] Murat FJ, Gettman MT. Free-floating organized fat necrosis: rare presentation of pelvic mass managed with laparoscopic techniques. Urology. 2004;63(1):176-7.

[18] Kao CH, Hsu KF, Fan HL, Li YF, Chen CJ. A case of intestinal obstruction caused by a peritoneal loose body mimicking gallstone ileus. Acta Gastroenterol Belg. 2010;73(3):413-4.

[19] Koga K, Hiroi H, Osuga Y, Nagai M, Yano T, Taketani Y. Autoamputated adnexa presents as a peritoneal loose body. Fertil Steril. 2010;93(3):967-8.

[20]20.Gayer G, Petrovitch I. CT diagnosis of a large peritoneal loose body: a case report and review of the literature. Br J Radiol.

[21] Nomura H, Hata F, Yasoshima T, Kuwahara S, Naohara $\mathrm{T}$, Nishimori $\mathrm{H}$, et al.Giant peritoneal loose body in the pelvic cavity: report of a case. Surg Today. 2003;33:791-3.

[22] Asabe K, Maekawa T, Yamashita Y, Shirakusa T. Endoscopic extraction of a peritoneal loose body: a case report of an infant. Pediatr Surg Int. 2005;21(5):388-9.

[23] Kim HS, Sung JY, Park WS, Kim YW. A giant peritoneal loose body. Korean J Pathol. 2013;47(4):378-82.

[24] Sahadev R, Nagappa PK. A case of peritoneal free floating calcifiedfibromyoma. $J$ Clin Diagn Res. 2014;8(5):ND03-4. 


\section{International Journal of Science and Research (IJSR) \\ ISSN (Online): 2319-7064}

Index Copernicus Value (2015): 78.96 | Impact Factor (2015): 6.391

[25] Jang JT, Kang HJ, Yoon JY, Yoon SG. Giant peritoneal loose body in the pelvic cavity. J Korean Soc Coloproctol. 2012;28(2):108-10.

[26] Nozu T, Okumura T. Peritoneal loose body. Intern Med. 2012;51(15):2057.

[27] Burns JB, Rogers Jr JV. A sequestered ovary as a loose peritoneal body. J South Med J. 1969;62(8):995-9.

[28] Maekawa T, Komine M, Murata S, Ohtsuki M. Peritoneal loose body: a case report and comparison with encapsulated fat necrosis. J Dermatol. 2013;40(12):1058-9.

[29] Makineni H, Thejeswi P, Prabhu S, Bhat RR. Giant peritoneal loose body: a case report and review of literature. J Clin Diagn Res. 2014;8(1):187-8.
[30] Allam T, Muzaffar R, Nguyen NC, Osman MM. Peritoneal mouse as detected on (18)F-FDG PET-CT. Front Oncol. 2013;3:83.

[31] Huang CH, Lin SC, Chang KC, Chow NH. Numerous peritoneal loose bodies with ileus. Histopathology. 2011;58(2):318-9.

[32] Ooyagi $H$, Ishida $H$, Komatsuda $T$, Yagisawa $H$. Peritoneal loose body. J Med Ultrason 2006; 33: 18990.

[33] Takayama S, Sakamoto M, Takeyama H. Clinical challenges and images in GI. Image 1: huge peritoneal loose body in the pelvic cavity. Gastroenterology 2009; 136: 404, 730 .

Table 1: Summary of the information of 24 cases in the literature

\begin{tabular}{|c|c|c|c|c|c|c|c|}
\hline Author & Published year & Gender & Age & Symptoms & Size of PLB (mm) & $\begin{array}{c}\text { Weight of } \\
\text { PLB }(\mathrm{g})\end{array}$ & $\begin{array}{l}\text { Surgical } \\
\text { methods }\end{array}$ \\
\hline Mohri et al. [8] & 2007 & $\mathrm{M}$ & 73 years & Abdominal pain & $95 \times 75 \times 66$ & 220 & Open \\
\hline Hedawoo and Wagh [16] & 2010 & $\mathrm{M}$ & 65 years & Abdominal pain & $95 \times 86$ & - & Open \\
\hline Murat and Gettman [17] & 2004 & $\mathrm{M}$ & 47 years & Pelvic pain & $35 \times 28 \times 25$ & - & Laparoscopy \\
\hline Bhandarwar et al. [4] & 1996 & $\mathrm{M}$ & 65 years & Acute retention of urine & $90 \times 80$ & 210 & Open \\
\hline Shepherd [7] & 1951 & M & 79 years & Acute retention of urine & $70 \times 55$ & - & Open \\
\hline Sewkani et al. [14] & 2011 & $\mathrm{M}$ & 64 years & Abdominal pain & $70 \times 50$ & 74 & Open \\
\hline Ghosh et al. [3] & 2006 & $\mathrm{M}$ & 63 years & Intestinal obstruction & $\begin{array}{c}58 \times 45 \times 37 \text { and } 52 \\
\times 45 \times 37\end{array}$ & - & Open \\
\hline Kao et al. [18] & 2010 & $\mathrm{~F}$ & 69 years & Intestinal obstruction & $40 \times 30 \times 23-$ & - & Open \\
\hline Kogao et al. [19] & 2010 & $\mathrm{~F}$ & 33 years & infertility & $30 \times 20-$ & - & Laparoscopy \\
\hline Gayer and Petrovitch [20] & 2011 & $\mathrm{M}$ & 59 years & Incidental & 30 & - & Untreated \\
\hline Nomura et al. [21] & 2003 & $\mathrm{M}$ & 63 years & Incidental & $50 \times 40 \times 30$ & - & Laparoscop \\
\hline Asabe et al. [22 ] & 2005 & $\mathrm{~F}$ & 2 months & Urinary tract infection & 30 & - & Laparoscopy \\
\hline Kim et al. [23] & 2013 & $\mathrm{M}$ & 50 years & Incidental & $175 \times 70 \times 68$ & 160 & Laparoscopy \\
\hline Sahadev and Nagappa [24] & 2014 & $\mathrm{M}$ & 52 years & Abdominal pain & $70 \times 60$ & - & Laparoscopy \\
\hline Jang et al. [25] & 2012 & $\mathrm{M}$ & 60 years & Incidental & $45 \times 40 \times 30$ & - & Laparoscopy \\
\hline Nozu and Okumuta [26] & 2012 & $\mathrm{M}$ & 67 years & incidental & 40 & - & Untreated \\
\hline Burns and James [27] & 1969 & $\mathrm{~F}$ & 33 years & Incidental & $18 \times 13$ & - & Open \\
\hline Maekawa [28] & 2013 & $\mathrm{M}$ & 58 years & Incidental & 20 & - & Open \\
\hline Makineni et al. [29] & 2014 & $\mathrm{M}$ & 52 years & Abdominal discomfort & 60 & - & Open \\
\hline Allam et al. [30] & 2013 & M & 77 years & Abdominal pain & 17 & - & Untreated \\
\hline Huang et al. [31] & 2011 & $\mathrm{M}$ & 55 years & Intestinal obstruction & - & - & Open \\
\hline Takada et al. [6] & 1998 & $\mathrm{M}$ & 79 years & Incidental & $70 \times 60$ and $70 \times 60$ & 78 and 66 & Open \\
\hline Ooyagi et al. [32] & 2006 & $M$ & 65 years & Abdominal discomfort & $4 \mathrm{~cm}$ diameter & - & Not available \\
\hline Takayama et al. [33] & 2009 & $\mathrm{M}$ & 63years & Abdominal discomfort & 4.5 diameter & - & Laparoscopy \\
\hline Our study & 2016 & M & 70years & Acute abdominal pain & $5 \mathrm{~cm}$ diameter & - & laparoscopy \\
\hline
\end{tabular}

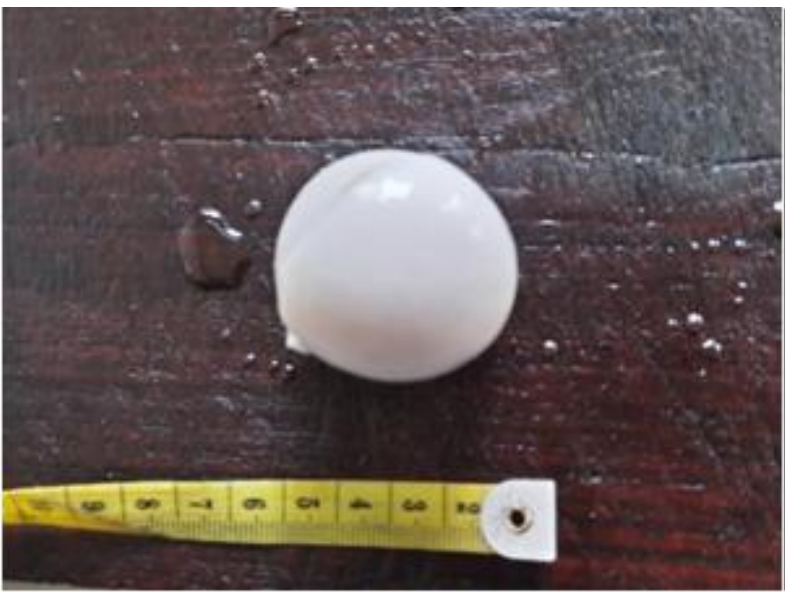

a.

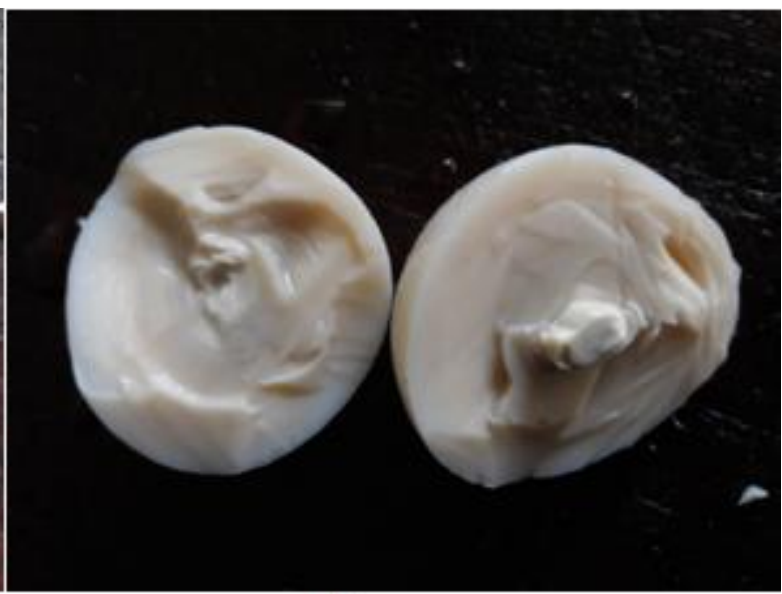

b.

\section{Volume 6 Issue 1, January 2017 www.ijsr.net}




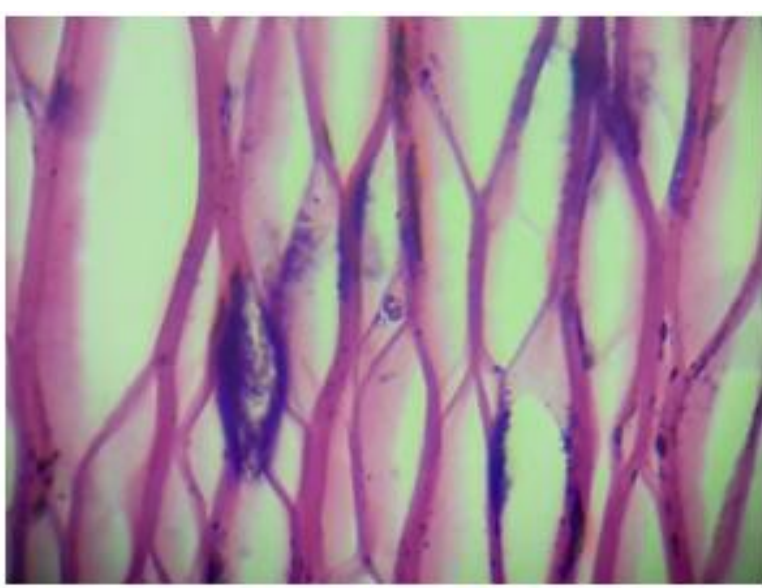

c.

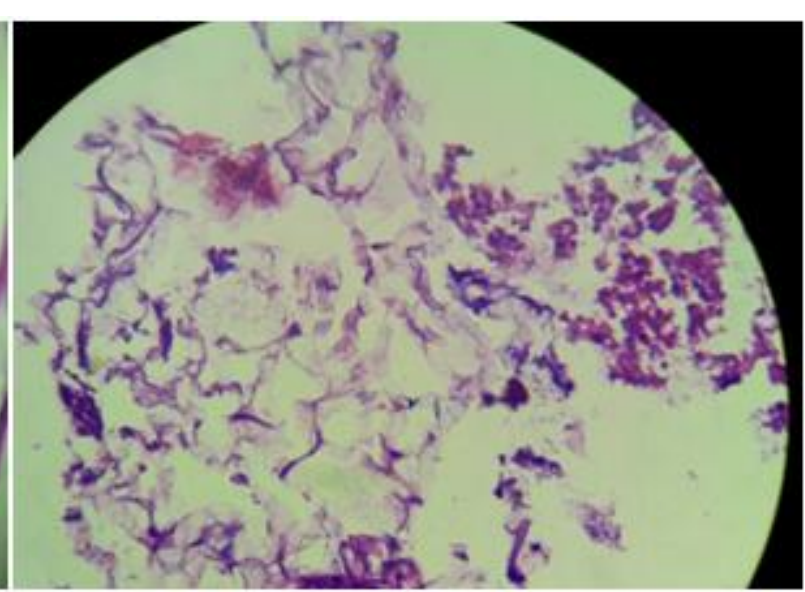

d.

Figure a: Boiled egg like mass measuring $5 \mathrm{~cm}$ diameter with smooth and shiny outer surface.

Figure b: cut surface showing central most hard core surrounded by yellowish rim. Peripheral part is whitish in colour.

Figure c: high power view showing dystrophic calcification.

Figure d: microscopic examination of omentum showing fat necrosis.

Volume 6 Issue 1, January 2017

www.ijsr.net 